\title{
A Comparison of Playfulness Levels of the Secondary Students in Kayseri and Trabzon Cities
}

\author{
Muhsin Hazar (Associate Professor) \\ Gazi University Sport Sciences Faculty, Ankara, Turkey \\ Malik Beyleroglu (Associate Professor) \\ Sakarya University Sport Sciences Faculty, Sakarya, Turkey \\ Emre Ozan Tingaz (Research Assistant) \\ Gazi University Sport Sciences Faculty, Ankara, Turkey \\ Belgin Gokyurek (Assistant Professor) \\ Gazi Üniversitesi Spor Bilimleri Fakültesi, Ankara, Turkey \\ Oguz Kaan Esenturk (Research Assistant) \\ Gazi University Sport Sciences Faculty, Ankara, Turkey
}

Doi: 10.19044/esj.2017.v13n29p58 URL:http://dx.doi.org/10.19044/esj.2017.v13n29p58

\begin{abstract}
The aim of the study is to draw a comparison of 11-14 age group secondary school students playfulness level to play games which consist of physical activity. It also aims to evaluate playfulness level in terms of various parameters. For this purpose, 11-14 age group students' playfulness level were examined according to cities, gender, and ages. A total of 52311 14 year-old students, including 303 from Kayseri and 220 from Trabzon, and some various schools formed a study group for the research conducted in the relational model. "Playfulness scale for playing games that consist of physical activity of children of 10-14 age group" that was developed by Hazar (2014) was used in the data collection. Based on the research, the level of playfulness of the participants was found to be "good" at 3.40-4.19. Students living in Kayseri and Trabzon were found to have "good" in terms of social adaptation, wish to play game, wish to win, and in general. Students in Kayseri "good" level had a playfulness at "medium" level in Trabzon. Due to the comparison of male and female student scores, it was found that there was a significant difference in favor of male students in game play overall, game passion, and risk taking dimensions. Girls are more likely to have social adaptation, playfulness, and a meaningful difference generally. Also, girls who live in Kayseri are more likely to be students. They wish to play game, social adaptation, wish to win, and risk taking. Meaningful differences can however be seen based on the scores of the 11 and 12 year students.
\end{abstract}


Keywords: Playfulness, 11-14 years of age, physical activity play

\section{Introduction}

Despite the fact that the functions of the game have a certain amount of prescription in each age group and every kind of game, it is of significant importance to children at the stage of development. First of all, the game for the child is a necessity. As a result, the child will be happy while playing the game. Since the game is closely related to the whole development of the child, attention in contemporary countries has turned to the activities of childhood play. Requirements in the areas of nutrition, love, and care for healthy child growth and development is also a necessary aspect of the game (Hazar, 2006; Koçyiğit ve ark., 2007; Mengütay, 1999).

When playing a game, the child does not only develops physically, but also develops in cognitive and affective areas. He learns creativity, problem-solving skills, productivity, struggle spirit, social interaction, solidarity, curiosity, and catches a lot of fun with the games (Auerbach, 2008; Başal, 2011; Byl, 2002).

Consequently, examination of the "playfulness" word structure used in the study will bring clarity to the concept. The term "-sal" in Turkish, which is the equal of "-ful" in English, gives the meaning of "relevancy, connectivity and belonging" to the names. "Playfulness states everything regarding games. The objective of "- ness" in English, which is the equal one of "-l1k in Turkish, is that this particle gives the "qualification, feature" to the names or adjectives by generalizing their meanings" (Zülfikar, 1991). In other words, the term "playfulness" generalizes the term "playful" and adds qualification to this word.

\section{Method}

The aim of this study is to evaluate the playfulness levels of 11-14 year old middle school students for playing physical activity games and the playfulness levels for gender, age, and province variables. A total of 523 1114 year-old students, including 303 from Kayseri and 220 from Trabzon, and some various school formed a study group for the research conducted. This was done using a purposeful sampling method.

The research was conducted in a relational screening model. Relational search models are research models which aims to determine the presence and / or extent of change between two or more variables (Karasar, 2014). 


\section{Study Group}

Participants were selected from Kayseri and Trabzon illusions, which were thought to exhibit different characteristics, using sampling for study purposes. However, the frequency and percentage distributions of the study group on the basis of the province where they are located are given in Table 1.

Table 1. Demographic Information

\begin{tabular}{|c|c|c|c|c|c|}
\hline \multirow{2}{*}{\multicolumn{2}{|c|}{ Variables }} & \multirow[b]{2}{*}{$\mathrm{f}, \%$} & \multicolumn{2}{|c|}{ Cities } & \multirow[b]{2}{*}{ Total } \\
\hline & & & Kayseri & Trabzon & \\
\hline \multirow{4}{*}{ Gender } & \multirow{2}{*}{ Girl } & $\mathrm{F}$ & 150 & 84 & 234 \\
\hline & & $\%$ & $64,1 \%$ & $35,9 \%$ & $100,0 \%$ \\
\hline & \multirow{2}{*}{ Boy } & $\mathrm{F}$ & 153 & 136 & 289 \\
\hline & & $\%$ & $52,9 \%$ & $47,1 \%$ & $100,0 \%$ \\
\hline \multirow{8}{*}{ Age } & \multirow{2}{*}{11 Age } & $F$ & 65 & 79 & 144 \\
\hline & & $\%$ & $45,1 \%$ & $54,9 \%$ & $100,0 \%$ \\
\hline & \multirow{2}{*}{12 Age } & $\mathrm{F}$ & 97 & 44 & 141 \\
\hline & & $\%$ & $68,8 \%$ & $31,2 \%$ & $100,0 \%$ \\
\hline & \multirow{2}{*}{13 Age } & $\mathrm{F}$ & 87 & 49 & 136 \\
\hline & & $\%$ & $64,0 \%$ & $36,0 \%$ & $100,0 \%$ \\
\hline & \multirow{2}{*}{14 Age } & $\mathrm{F}$ & 54 & 48 & 102 \\
\hline & & $\%$ & $52,9 \%$ & $47,1 \%$ & $100,0 \%$ \\
\hline \multirow{2}{*}{\multicolumn{2}{|c|}{ Total }} & $\mathrm{F}$ & 303 & 220 & 523 \\
\hline & & $\%$ & $57,9 \%$ & $42,1 \%$ & $100,0 \%$ \\
\hline
\end{tabular}

As seen in Table 1, a total of 523 students from the 11-14 age group, including 220 from 303 Trabzon from Kayseri, participated in the study. There are 234 female students and 289 male students. $64.1 \%$ of the girls are from Kayseri and $35.9 \%$ are from Trabzon. $52.9 \%$ of the male students are from Kayseri and $47.1 \%$ are from Trabzon. Based on the 11-14 age group students from whom the study was conducted, 144 were 11 years, 141 were 12 years, 136 were 13 years, and 102 were 14 years. In this study, 54.9\% of the 11 year old students are from Trabzon, $68.8 \%$ of the 12 year old students are from Kayseri, $64.0 \%$ of the 13 year old students are from Kayseri, and $52.9 \%$ of the 14 year old students are from Kayseri who joined and constituted the majority.

\section{Data Collection Tool}

In the research developed by Hazar (2014) for 10-14 age group children, "Playfulness" scale were used. The students in this study also met the age group within the boundaries of the scale and they are between the ages of 11-14. The scale has a structure with five sub-factors of 27 items. These sub-factors are; Game passion, social harmony, game desire, desire to win, and risk taking. The 27 -item Cronbach alpha score of the scale is 0.82 . 
Alpha values of subscales of the scale are; Game passion is 0.73 , social adjustment is 0.82 , game request is 0.64 , desire to win is 0.61 , and risk taking is 0.63 .

\section{Analysis of Data}

SPSS 22.00 package program was used in the study. After the data was transferred to the computer, the Kolmogorov-Simirnov test was conducted to test the appropriateness of the normal distribution of the playfulness scores of the students. This was done in the direction of the sub problems. The level of playfulness of the students was determined using the arithmetic mean and standard deviation of the descriptive techniques. In addition, Mann Whitney-U for nonparametric tests and Kruskal-Wallis test for two variables were used. The Mann Whitney-U test was conducted to identify the source of the difference in the resulting situations in this test result. The alpha value calculated on the playfulness scale for the 10-14 age group which was developed by Hazar (2014) was 0.82. In addition, the reliability of the scale was calculated as 0,70 in this research.

The interpretation of the data used the following range of points:

Table 2. Playfulness and sub-factors level ranges

\begin{tabular}{cc}
\hline Level of playfulness and sub-factors & Score intervals \\
\hline Very week & $1.00-1.79$ \\
\hline Week & $1.80-2.59$ \\
\hline Moderate & $2.60-3.39$ \\
\hline Good & $3.40-4.19$ \\
\hline Vey good & $4.20-5.00$ \\
\hline
\end{tabular}

\section{Findings}

Findings obtained in the research are given below according to sub problems.

\section{The Level of Playfulness of the Students}

For the level of playfulness of the students, regardless of the province, arithmetic average and standard deviation were used. Thus, the findings are given in Table 3.

Table 3. Level of Playfulness of Students

\begin{tabular}{cccccc}
\hline Sub-Dimensions and Scale & $\mathrm{N}$ & $\overline{\mathbf{X}}$ & Ss & Minimum & Maximum \\
\hline Game Passion & 523 & 2,77 & 0,77 & 1,14 & 4,86 \\
\hline Social Adaptation & 523 & 3,99 & 0,83 & 1,00 & 5,00 \\
\hline Wish to play game & 523 & 3,57 & 0,96 & 1,00 & 5,00 \\
\hline Wish to win & 523 & 3,74 & 1,05 & 1,00 & 5,00 \\
\hline Taking Risk & 523 & 2,91 & 0,98 & 1,00 & 5,00 \\
\hline General & 523 & 3,44 & 0,56 & 1,52 & 4,81 \\
\hline
\end{tabular}


From the data obtained in Table 3 , social adaptation $(3,99)$, wish to win $(=3,74)$, wish to play game $(=3,57)$, and general $(=3,44)$ playfulness is "good". Sub-dimensions with low level of playfulness were according to the above dimensions; $=2.91$ average with risk taking and $=2.77$ average with game passion sub-dimension. In these dimensions, the average score of the students is "medium".

\section{Comparison of Playfulness Levels of Students according to Province Variable}

The Mann Whitney-U test was used for independent samples to determine whether there was a statistically significant difference in playfulness level according to the provincial variables of the students. Thus, the findings obtained are given in Table 4 below.

Table 4. Mann Whitney-U Test in terms of province variable

\begin{tabular}{|c|c|c|c|c|c|c|}
\hline Sub-Dimensions & Province & $\mathrm{N}$ & Mean Rank & Rank Sum & $\mathrm{U}$ & $\mathrm{p}$ \\
\hline \multirow{2}{*}{ Game Passion } & Kayseri & 303 & 269,98 & 81802,50 & \multirow{2}{*}{30913,500} & \multirow{2}{*}{, 15} \\
\hline & Trabzon & 220 & 251,02 & 55223,50 & & \\
\hline \multirow{2}{*}{ Social Adaptation } & Kayseri & 303 & 276,46 & 83768,50 & \multirow{2}{*}{28947,500} & \multirow{2}{*}{, $01 *$} \\
\hline & Trabzon & 220 & 242,08 & 53257,50 & & \\
\hline \multirow{2}{*}{$\begin{array}{c}\text { Wish to play } \\
\text { game }\end{array}$} & Kayseri & 303 & 276,15 & 83674,00 & \multirow{2}{*}{29042,000} & \multirow{2}{*}{, $01 *$} \\
\hline & Trabzon & 220 & 242,51 & 53352,00 & & \\
\hline \multirow{2}{*}{ Wish to win } & Kayseri & 303 & 255,96 & 77556,00 & \multirow{2}{*}{31500,000} & \multirow{2}{*}{, 28} \\
\hline & Trabzon & 220 & 270,32 & 59470,00 & & \\
\hline \multirow{2}{*}{ Taking Risk } & Kayseri & 303 & 262,05 & 79401,00 & \multirow{2}{*}{33315,000} & \multirow{2}{*}{, 85} \\
\hline & Trabzon & 220 & 261,93 & 57625,00 & & \\
\hline \multirow{2}{*}{ General } & Kayseri & 303 & 275,75 & 83553,50 & \multirow{2}{*}{29162,500} & \multirow{2}{*}{, $02 *$} \\
\hline & Trabzon & 220 & 243,06 & 53472,50 & & \\
\hline
\end{tabular}

As seen in Table 4, there is a significant difference between playfulness dimensions and play fit dimensions of social harmony and playfulness scores of students in Kayseri and Trabzon $(p<0,05)$. When the mean rank is examined, it was seen that this difference arises because student scores in Kayseri are higher than student scores in Trabzon.

While the scores of the students in Kayseri are higher in the dimension of the game passion with no meaningful difference, the scores of the students in Trabzon are higher in the aspect of desire to win. In the dimension of risk taking, the mean rank of the playfulness level of the students is close to each other. 


\section{Levels of Playfulness in General by Gender}

Mann Whitney-U test was used for two independent samples in which there was a significant difference in playfulness according to gender variable. The results of the analysis are given in Table 5 below.

Table 5. Mann Whitney-U Test in terms of gender variable

\begin{tabular}{|c|c|c|c|c|c|c|}
\hline Dimensions & Gender & $\mathrm{N}$ & Mean Rank & Rank Sum & $\mathrm{U}$ & $\bar{p}$ \\
\hline \multirow{2}{*}{ Game Passion } & Girl & 234 & 224,28 & 52480,50 & \multirow{2}{*}{24985,500} & \multirow{2}{*}{, $00 *$} \\
\hline & Boy & 289 & 292,54 & 84545,50 & & \\
\hline \multirow{2}{*}{ Social Adaptation } & Girl & 234 & 255,65 & 59822,50 & \multirow{2}{*}{32327,500} & \multirow{2}{*}{,38 } \\
\hline & Boy & 289 & 267,14 & 77203,50 & & \\
\hline \multirow{2}{*}{ Wish to play game } & Girl & 234 & 249,99 & 58498,00 & \multirow{2}{*}{31003,000} & \multirow{2}{*}{, 10} \\
\hline & Boy & 289 & 271,72 & 78528,00 & & \\
\hline \multirow{2}{*}{ Wish to win } & Girl & 234 & 272,34 & 63728,50 & \multirow{2}{*}{31392,500} & \multirow{2}{*}{,15 } \\
\hline & Boy & 289 & 253,62 & 73297,50 & & \\
\hline \multirow{2}{*}{ Taking Risk } & Girl & 234 & 237,92 & 55674,00 & \multirow{2}{*}{28179,000} & \multirow{2}{*}{, $00 *$} \\
\hline & Boy & 289 & 281,49 & 81352,00 & & \\
\hline \multirow{2}{*}{ General } & Girl & 234 & 237,75 & 55633,50 & \multirow{2}{*}{28138,500} & \multirow{2}{*}{, $00 *$} \\
\hline & Boy & 289 & 281,63 & 81392,50 & & \\
\hline
\end{tabular}

When the data in Table 5 regarding the gender variable were examined (Game passion, risk taking and general playfulness), male students score higher than female students. The difference between the scores of male and female students was found to be statistically significant $(p<0.05)$. In the framework of this finding, it can be said that male students are more passionate and play a higher level of risk.

\section{Levels of Playfulness in General by Age}

The Kruskall Wallis test was applied to more than two independent samples in order to determine whether the playfulness levels of the students were significantly different according to age variables. Thus, the results are presented in Table 6.

Table 6. Playfulness levels of the female students in terms of ages

\begin{tabular}{|c|c|c|c|c|c|c|}
\hline Dimensions & Age & $\mathrm{N}$ & Mean Rank & $X^{2}$ & sd & $\mathrm{p}$ \\
\hline \multirow{4}{*}{ Game Passion } & 11 Age & 144 & 284,83 & \multirow{4}{*}{13,460} & \multirow{4}{*}{3} & \multirow{4}{*}{, $01 *$} \\
\hline & 12 Age & 141 & 281,56 & & & \\
\hline & 13 Age & 136 & 245,28 & & & \\
\hline & 14 Age & 102 & 225,03 & & & \\
\hline \multirow{4}{*}{ Social Adaptation } & $11 \mathrm{Age}$ & 144 & 278,64 & \multirow{4}{*}{19,157} & \multirow{4}{*}{3} & \multirow{4}{*}{, $00 *$} \\
\hline & 12 Age & 141 & 295,65 & & & \\
\hline & $13 \mathrm{Age}$ & 136 & 240,46 & & & \\
\hline & 14 Age & 102 & 220,72 & & & \\
\hline \multirow{4}{*}{ Wish to play game } & $11 \mathrm{Age}$ & 144 & 288,47 & \multirow{4}{*}{18,140} & \multirow{4}{*}{3} & \multirow{4}{*}{, $00 *$} \\
\hline & 12 Age & 141 & 279,39 & & & \\
\hline & 13 Age & 136 & 253,54 & & & \\
\hline & 14 Age & 102 & 211,86 & & & \\
\hline Wish to win & $11 \mathrm{Age}$ & 144 & 269,57 & ,948 & 3 & 81 \\
\hline
\end{tabular}




\begin{tabular}{|c|c|c|c|c|c|c|}
\hline & 12 Age & 141 & 261,13 & & & \\
\hline & 13 Age & 136 & 263,26 & & & \\
\hline & 14 Age & 102 & 250,82 & & & \\
\hline \multirow{4}{*}{ Taking Risk } & 11 Age & 144 & 236,25 & \multirow{4}{*}{5,522} & \multirow{4}{*}{3} & \multirow{4}{*}{, $03 *$} \\
\hline & 12 Age & 141 & 242,86 & & & \\
\hline & 13 Age & 136 & 257,42 & & & \\
\hline & 14 Age & 102 & 276,45 & & & \\
\hline \multirow{4}{*}{ General } & 11 Age & 144 & 275,03 & \multirow{4}{*}{15,078} & \multirow{4}{*}{3} & \multirow{4}{*}{, $00 *$} \\
\hline & 12 Age & 141 & 293,22 & & & \\
\hline & 13 Age & 136 & 242,86 & & & \\
\hline & 14 Age & 102 & 225,96 & & & \\
\hline
\end{tabular}

When Table 6 was examined, it was seen that there was a meaningful difference in game passion, social adaptation, wish to play game, risk taking dimensions, and playfulness in general. This is beside the desire dimensions according to age variable $(\mathrm{p}<0,05)$. According to this finding, it can be said that age variable is an effective factor based on the level of playfulness.

A Mann Whitney-U test was conducted to ascertain the age and the significant differences where the age variable originated. This is shown in Table 7 below.

Table 7. Mann Whitney-U test results

\begin{tabular}{|c|c|c|c|c|c|c|}
\hline Dimensions & Yaş & $\mathrm{N}$ & $\begin{array}{c}\text { Sira } \\
\text { Ortalamas } 1 \\
\end{array}$ & $\begin{array}{c}\text { Sira } \\
\text { Toplamı } \\
\end{array}$ & $\mathrm{U}$ & $\mathrm{p}$ \\
\hline \multirow{4}{*}{ Game Passion } & $11 \mathrm{Age}$ & 144 & 134,97 & 19436,00 & \multirow{2}{*}{5692,000} & \multirow{2}{*}{, $00 *$} \\
\hline & 12 Age & 102 & 107,30 & 10945,00 & & \\
\hline & 13 Age & 141 & 132,79 & 18723,00 & \multirow{2}{*}{5670,000} & \multirow{2}{*}{, $01 *$} \\
\hline & 14 Age & 102 & 107,09 & 10923,00 & & \\
\hline \multirow{4}{*}{ Social Adaptation } & 11 Age & 144 & 135,33 & 19488,00 & \multirow{2}{*}{5640,000} & \multirow{2}{*}{, $00 *$} \\
\hline & 12 Age & 102 & 106,79 & 10893,00 & & \\
\hline & 13 Age & 141 & 136,63 & 19265,00 & \multirow{2}{*}{5128,000} & \multirow{2}{*}{, $00 *$} \\
\hline & 14 Age & 102 & 101,77 & 10381,00 & & \\
\hline \multirow{4}{*}{ Wish to play game } & $11 \mathrm{Age}$ & 144 & 138,16 & 19894,50 & \multirow{2}{*}{5233,500} & \multirow{2}{*}{, $00 *$} \\
\hline & 12 Age & 102 & 102,81 & 10486,50 & & \\
\hline & 13 Age & 141 & 135,24 & 19069,50 & \multirow{2}{*}{5323,500} & \multirow{2}{*}{, $00 *$} \\
\hline & 14 Age & 102 & 103,69 & 10576,50 & & \\
\hline \multirow{2}{*}{ Taking Risk } & 11 Age & 144 & 108,28 & 10965,50 & \multirow{2}{*}{5948,500} & \multirow{2}{*}{, $01 *$} \\
\hline & 12 Age & 102 & 132,28 & 13492,50 & & \\
\hline \multirow{4}{*}{ General } & 13 Age & 144 & 133,15 & 19173,00 & \multirow{2}{*}{5955,000} & \multirow{2}{*}{, $01 *$} \\
\hline & 14 Age & 102 & 109,88 & 11208,00 & & \\
\hline & 11 Age & 141 & 134,67 & 18988,00 & \multirow{2}{*}{5405,000} & \multirow{2}{*}{, $00 *$} \\
\hline & 12 Age & 102 & 104,49 & 10658,00 & & \\
\hline
\end{tabular}


According to the information in Table 7, it was observed that the students in the 11th and 12th age groups are higher than the student scores in the 14th grade in terms of the differences in dimensions and, in general, the rank average of the students. In other words, the scores of game passion, social adaptation, wish to game, risk taking, and generally meaningful difference are the scores of 11 and 12 year old students. This findings can be reached as the age increases and as the level of playfulness changes.

\section{Results}

The findings on the playfulness levels of 11-14 age group students reached the following results:

1. The level of playfulness of the participants was found to be "good" at 3.40-4.19.

2. Students living in Kayseri and Trabzon were found to have "good" in terms of social adaptation, wish to play game, wish to win, and in general. Students in Kayseri "good" level had a playfulness at "medium" level in Trabzon. Despite having the same size and playfulness at the same level, it was thought that there is a difference due to the lower scores of the residents in Trabzon.

3. According to the province variable, social cohesion and game desire, a significant difference were found generally. Also, there was no difference at 0.05 level in other dimensions in which this difference was favored by the students who reside in Kayseri.

4. Comparison of Male and Female Student Scores: It was found that there was a significant difference in favor of male students in game play overall, game passion, and risk taking dimensions. Girls are more likely to have social adaptation, playfulness, and generally a meaningful difference. Also, girls who live in Kayseri are more likely to be students. It was observed that the scores of the students in Kayseri and the male students in Trabzon were higher than those students in Kayseri in terms of wish to play games and wish to win in male students.

5. Wish to play game, social adaptation, wish to win, risk taking, and generally meaningful differences are the scores of the 11 and 12 year students.

\section{Recommendations}

From this research, the relation between playfulness level, education level, family structure, income level and education level of the family, desire to move to physical activities, sustainability of sportive studies, and branching and sporting success can be sought. 


\section{References:}

1. Auerbach, S. (2008). Anne Babalar için Çocuk Yetiştirmede Oyunun Önemi. İstanbul: $\quad$ Yakamoz Yayıncılık; 20-23.

2. Barnett, L. A. \& Kleiber, D. A. (1982). Concomitants of Playfulness in Early Childhood: Cognitive Abilities and Gender. Journal of Genetic Psychology, 141 (1), 115-127.

3. Berretta, L. A. \& Privette, G. (1990). Influence of Play on Creative Thinking. Perceptual and Motor Skills, 71, 659-666.

4. Başal, H. A. (2011). Geçmişten Günümüze Türkiye'de Geleneksel Çocuk Oyunlarl. İstanbul: Mopa Kültür Yayınları; 10-11.

5. Byl, J. (2002). Co-EdRecreational Games. USA: VersaPress, p.xxv.

6. Hazar, M. (2006). Beden Eğitimi ve Sporda Oyunla Eğitim. (5. bask1). Ankara: Tutibay Ltd. Şti.

7. Hazar, M. (2014). The Attitudes Of 10-14 Years Old Children Against The Act Of Playing Games Requiring Physical Activity. International Journal of Academic Research. 6(6).

8. Hazar, M. (7-8 May1s 2015). 10-14 Yaş Grubu Ortaokul Öğrencilerinin Aktif Oyunları Oynamaya Yönelik Oyunsallık Düzeyleri. Uluslararası Oyun ve Oyuncak Kongresinde Sözel Bildiri Olarak Sunulmuştur, Erzurum.

9. Hazar, M., Yıldız, M., Baydar, H. Ö., \& Karaçam, A. (2015). Assesment of Playfulness Among the Children Aged 10-14 Years. The Antropologist, International Journal of Contemporary and Applied Studies of Man, 22 (1): 50-58.

10. Karasar, N. (2014). Bilimsel Araştırma Yöntemi. Ankara: Nobel Yayın Dağıtım.

11. Koçyiğit, S., Tuğluk, M. N., Kök, M. (2007). Çocuğun Gelişim Sürecinde Eğitsel Bir Etkinlik Olarak Oyun. Kazım Karabekir Eğitim Fakültesi Dergisi, (16), 324-342.

12. Mengütay, S. (1999). Okulöncesi ve Illkokullarda Hareket Gelişimi ve Spor. Ankara: Tutibay Ltd. Şti.

13. Murdock, G. (7-8 May 2015). Imaginative Enclosures: Materlal Children at Play in Digital Times. International Play And Toy Congress, Proceedings Books;12, Erzurum.

14. Proyer, R. T. (2011). Being Playful and Smart? The Relations of Adult Playfulness with Psychometric and Self-estimated Intelligence and Academic Performance. Learning and Individual Differences, 21 (4), 463-467.

15. Singer, D. C., Singer, J. L. (1978). Some correlates of imaginative play in preschoolers. Paper presented at the Annual Meeting of the American Psychological Association, 86th, Toronto, Canada, August 28-September 1. 
16. Trevlas. E., Matsouka, O., \& Zachopoulou, E. (2003). Relationship between Playfulness and Motor Creativity in Preschool Children. Early Child Development Care, 173 (5), 535-543.

17. Zülfikar, H. (1991). Terim Sorunları ve Terim Yapma Yolları. Ankara: Türk Dil Kurumu Yayınları. 